\title{
Belphégor
}

\section{Fantomas 1921 - A Tale of a Lost American Movie Serial}

\section{David White}

\section{(2) OpenEdition \\ 1 Journals}

\section{Electronic version}

URL: http://journals.openedition.org/belphegor/194

DOI: 10.4000/belphegor.194

ISSN: 1499-7185

Publisher

LPCM

\section{Electronic reference}

David White, «Fantomas 1921 - A Tale of a Lost American Movie Serial », Belphégor [Online], 11-1। 2013, Online since 01 May 2013, connection on 20 June 2020. URL : http://journals.openedition.org/ belphegor/194 ; DOI : https://doi.org/10.4000/belphegor.194

This text was automatically generated on 20 June 2020 .

\section{(c) (i) (9)}

Belphégor est mis à disposition selon les termes de la Licence Creative Commons Attribution - Pas d'Utilisation Commerciale - Pas de Modification 4.0 International. 


\title{
Fantomas 1921 - A Tale of a Lost American Movie Serial
}

\author{
David White
}

\section{Document 1}

\section{More Millions Await Exhibitors Who Play "Fantomas"}

THE second William Fox Serial, "Fantomas," has behind it all the possibilities that 1 made the first Fox serial, "Bride 13," so great a "puller."

"Bride 13" has been called the "greatest serial ever shown."

"Fantomas" is a greater one. It has behind it the celebrated detective stories of Marcel Allain and Pierre Souvestre, the great French authors whose works have been read by millions.

It is an up-to-the-second 1921 production and has in it modern photography, modern sets unsurpassed by any serial ever put on the market for showmen who want to crowd their houses. It will have more drawing power than a feature.

Any exhibitor who sees this serial will readily recognize the fact that money was not spared on its production. It was made second to none, so that the exhibitors of the country could get larger patronage and hold that patronage week after week.

It is in twenty thrilling episodes.

GET BEHIND IT with a BIG AND EARLY PUBLICITY CAMPAIGN, and your banker will KNOW YOU HAVE STRUCK GOLD. Let your competitor worry about the future. You book "Fantomas" and you will have twenty weeks' big business.

1 Fantomas is one of the great literary fictional characters of all time - the very archetype of the master criminal who has influenced popular culture in dozens of genres and media. Crack open a paperback thriller from virtually any country and you can draw a line between the antagonist and Fantomas. Slap an action film from any decade onto your DVD player and Fantomas will likely show himself, even if it's only in 
faint traces or wisps of narrative smoke. Anytime a character rears his or her head and becomes evil personified, that is Fantomas, making himself known to audiences and readers over and over and over again.

2 And yet in America, even pop culture aficionados with idiot-savant-like knowledge of comics, pulps and movies have seldom heard of him. While the descendants of Allain and Souvestre's creation - characters like Goldfinger or the Joker - are well known, Fantomas lacks name recognition in the US. The trilogy of films directed by Andre Hunabelle in the 1960s never made the kind of splash in America that they did elsewhere, and the famous comic book series that ran for decades in Mexico was never translated into English.

In the beginning, however, Fantomas was a known quantity in America with wide name recognition. Prior to World War II, the Fantomas novels were serialized in American newspapers, then issued in hardcover volumes. The Feuillade serials were quite successful in America, so much so that his later serial, Les Vampires, was marketed as a sequel to Fantomas.

$4 \quad$ It's difficult to know why Americans didn't develop a lasting taste for Fantomas the way many other countries did. Perhaps we were just too isolationist in the years after World War I. But there was a moment, in 1921 when Hollywood attempted to make Fantomas their own. While it's de rigueur for the motion picture industry to Americanize a foreign product these days, it wasn't yet an established practice during the beginning of the film industry. Nevertheless, in 1921, Fantomas made his American debut in a 20part serial directed by Edward Sedgwick for William Fox Films that was shot, completed and distributed to theatres around the United States and subsequently exported to France. Unfortunately, for many years that was just about all we knew about the serial. All twenty film episodes have vanished without a trace. Even publicity materials have been nearly impossible to track down, and multiple google searches only lead to paraphrases of the same information over and over again.

5 In 2005, during a frenzy of ebay purchasing, I obtained on a press book for the 1921 American version of Fantomas. While the document doesn't give us enough information to assess the serial from a qualitative standpoint, it does contain a plethora of fascinating images, stills, ads and press material that give us a glimpse into how an America movie company, Fox Films, attempted to Americanize a foreign product. On each of its twelve, oversized pages, there were at least a dozen articles or images. Ad mats were grouped together, as were stills, biographical information, plot synopsis and so on. The book was organized so that all the items could be easily photographed or clipped. Each page contained several and added to a newspaper layout. This might explain why complete copies are so difficult to find. 
Document 2

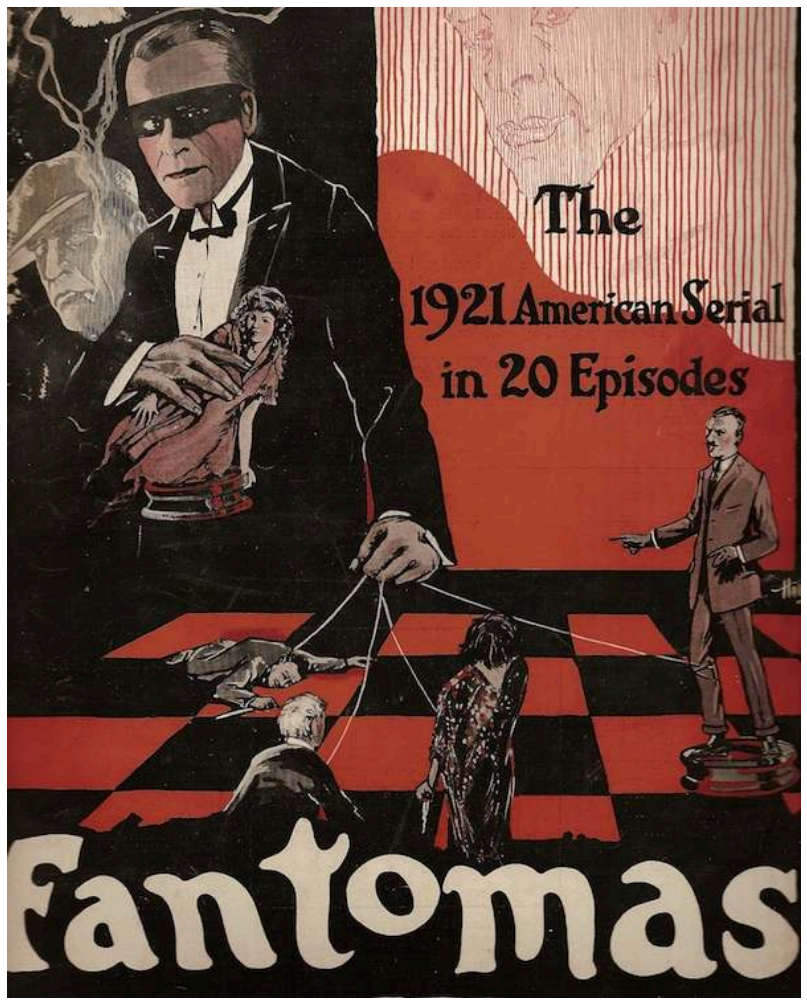

6 The cover illustration is a splendid rendition of an oversized Fantomas as puppet master, manipulating the other characters. It appears to be one of the only nods to Fantomas' status as a surrealist icon in the Fox serial. While the spirit of Fantomas was retained, director and screenwriter Edward Sedgwick junked the Allain and Souvestre source material. There is no Inspector Juve or Jerome Fandor or Sonia Danidoff. A Lady Beltham surrogate was created, but she carries the more enigmatic sobriquet, "The Lady in Black." 


\section{Document 3}

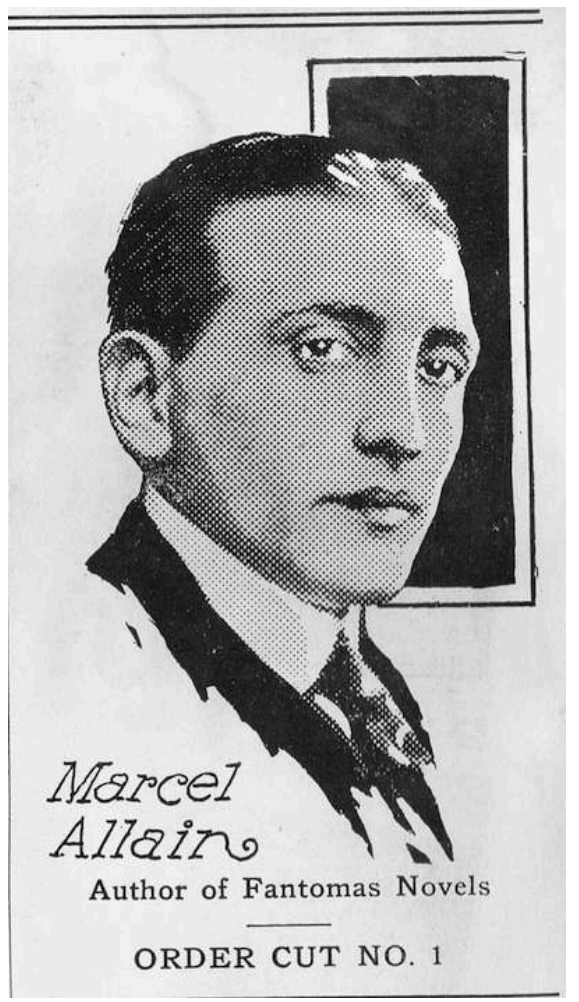

7 Although Allain and Souvestre are properly celebrated for their creation in the press materials, they are depicted in such a blatantly fictitious way - it is never mentioned, for instance, that Souvestre is dead - that some of the writing rivals the original novels themselves in terms of surrealist "automatic writing." Their prodigious output is discussed, but it is then followed by the following bizarre biographical detail, from an advance press clipping issued with the press book, that must be read to be believed:

"Speaking of their work, Marcel Allain said he and Souvestre had taken apart and examined several hundred different locks; and Allain remarked, without meaning to boast, that there was not a lock in the world he could not pick. They studied their work closely. If they came to a knotty problem they would work it out and get the human, not the imaginary, solution. For instance, they were walking along the streets of Paris one afternoon discussing a situation that develops in a halfdarkened room in the lower quarter of Paris. Allain had one opinion and Souvestre another. Suddenly, they saw outside a dilapidated building with the sign 'Room to let.' "Here's a room. We'll try out both theories," said Souvestre. They entered the building. The woman showed them the room. They told her to come back in ten minutes and that they wanted to talk over the advisability of taking the room. When she had one they locked the door, took off their coats and were fighting out their theories, making a terrible racket, when the woman returned and hearing the scuffle, ran out and brought in the police. The police pounded on the door. Allain and Souvestre kept at their work. The coming of the police, the knocking at the door, gave them added points to the theories. Then the police smashed in the door to confront two bedraggled men, who tried to explain what they were doing. The two authors were taken to the station house, where higher officials, knowing them, set them free."

8 The cast featured a number of well-known, at the time, actors in roles created especially for the chapter play by co-writers Edward Sedgwick and George Eshenselder. The press book contains character bios for all the principle players, although it's 
difficult to discern fact from fictional marketing material. John Willard took on the role of Detective Dixon - the Inspector Juve surrogate.

Document 4

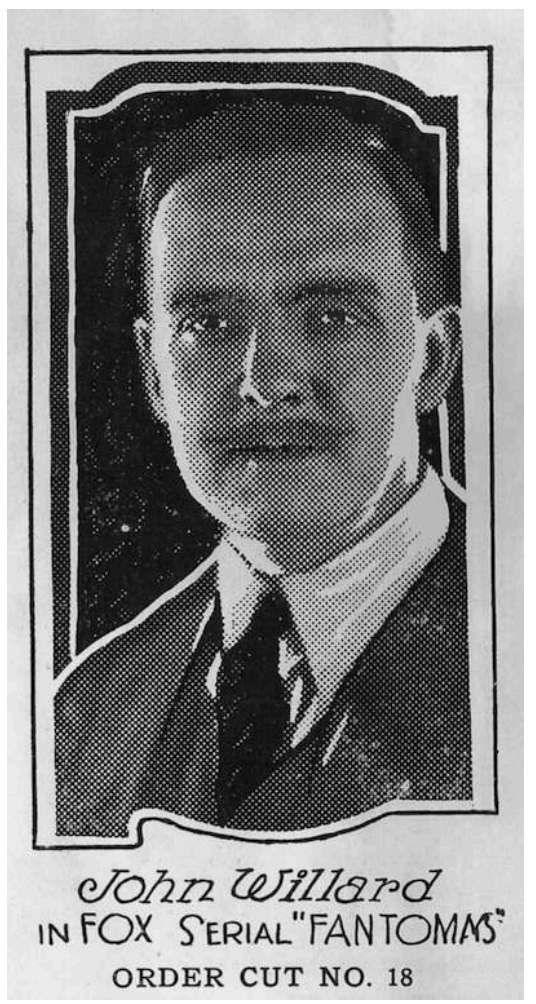

9 John Willard's bio on the internet movie database says little beyond the fascinating nugget of information that he was the man that wrote the original play The Cat and the Canary, and spent two years acting in the Broadway production. The press book, however, presents him as a truly continental artist and scholar, who studied in Ohio, Illinois, California, Paris, London and Italy. After stints as a gold miner and a cowboy (!), Willard then became an actor, appearing on Broadway in Within the Law and Very Good Eddie, as well as a writer of stage thrillers. In addition to Cat and the Canary, he wrote plays with marvelous, pulpy titles like The Gold Beetle, The Red Hate, The Blue Diamond and The Black Plague. In addition, he was a member of the Lambs Club of theater actors and playwrights in New York City.

Edna Murphy, who played the heroine Ruth Harrington, was well-known film actor of the day who appeared in over 80 motion pictures. Little of Murphy's film work remains and while there is slightly more biographical information about her on the web than Willard, the press book contains plenty of interesting facts. Murphy is painted a young girl who excelled in performing in amateur talent shows and shot her first motion picture as a teen without telling her parents (horrors!). When it came time to appear in Fantomas, director Edward Sedgwick had to talk her into it. It seems the dangers of appearing in a serial with so many stunts was a little alarming to the young Murphy. Eventually, she relented and says, “Now I just love playing in a serial! There isn't a chance of ever being bored, and it's rather fun doing the stunts! There's a lot of water stuff in it too and I enjoy that so much - even these cold days for I have always indulged 
in dips during the coldest winter weather." No doubt some viewers went to see Fantomas on the promise of being able to see Murphy in a wet, clingy dress.

\section{Document 5}

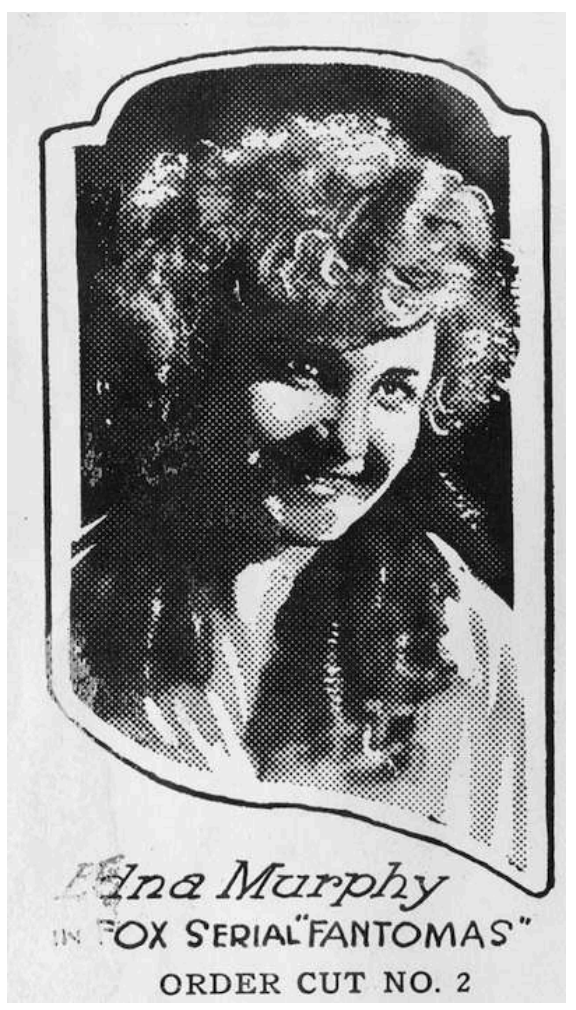

11 Eva Balfour played our Lady Beltham substitute, referred to here as "The Woman in Black." Balfour was apparently an important stage actress in England, although the press book neglects to give us any of her previous credits, focusing instead on her troubled relationship with her parents who had forbid her to go into acting. Never fear, however. They forgave her just in time for her to be cast in Fantomas. 


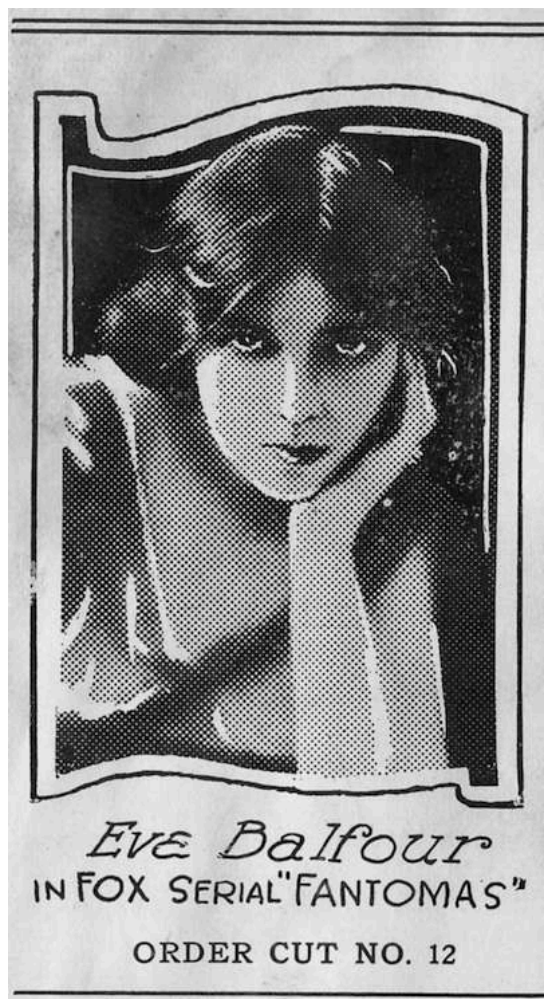

Playing Jack Meredith, Ruth Harrington's love interest, Johnny Walker was, along with Edna Murphy, the most well-known member of the cast and the pairing of he and Murphy as love interests was clearly a calculated move on the part of Fox. In their efforts to promote Meredith as an action hero, Fox created several press stories relating anecdotes about his two-fisted, rough housing nature. From the press book: "Johnny is young and will take a chance on anything. He told the director he could do the stunt all right. The building was on the edge of the water. It was a cold day. Johnnie started up with great spirit. But three-quarters up he began to tire. The finger and toe hold on the building was slim. Johnnie, breathless, stopped. He looked up. It was an awful distance to a tired man. Johnnie looked down. The cold water seemed to grin viciously at him. If he dropped, he would get wet. He would spoil the scene. He would be chilled to the bone!"

13 And finally we meet the man of the hour - Edward Roseman, the star of the great "lost" Fantomas. According to the press book, "Roseman was born in Terre Haute, Ind[iana]. After his schooling days he decided he would be a locomotive engineer. He had often been down at the station and seen the big engines come in and stop, and start on their way over the country - the hand of the engineer commanding the destinies of hundreds and sometimes thousands of travelers. It was a great life, somewhat wild; but the very wildness attracted his adventurous nature." The book goes on to relate a somewhat confusing anecdote involving mail trains and Roseman's inability to pay attention to his job while conversing with an attractive woman. The incident leads to his firing, which causes him to throw himself into amateur theatricals. He spent four years on the vaudeville touring circuit before drifting into the motion picture business. He had also appeared in Fox's previous serial, Bride 13. 


\section{Document 7}

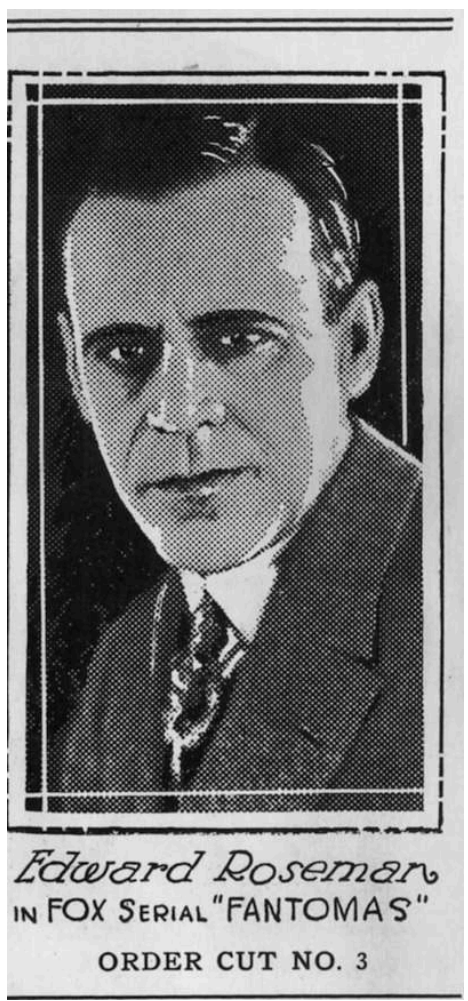

14 Thankfully, a slightly more detailed account of Roseman's pre and post-Fantomas life exists in the form of a brief article by journalist Mike McCormick that was published in the August 18, 2002 edition of the Terra Haute Tribune-Star that begins, "No Terre Haute native has appeared in more motion pictures than Edward Roseman." According to McCormick, who interviewed Roseman's 90 year-old niece, Ernest Frederick Roseman was born on May 14, 1875 to Henry Roseman, a pharmacist, and his wife, Mary. Henry died in 1882 of tuberculosis when he was 31, and Ernest was raised by his mother . He also had a sister, Jennie May, and a brother, (Henry).

Roseman appeared in 62 motion pictures and became known as "A Man of a Thousand Faces," before that title was claimed by Lon Chaney in the early 1920s. In a bit of coincidence that Fantomas aficionados will be able to appreciate, his first film, The Partners, was produced by the French film company Éclair, which had studios in Fort Lee, New Jersey. Roseman only appeared in one "talkie," The House of Secrets, in 1929. It was his last film before disappearing from the entertainment industry. After marrying Sophia Anderson, Roseman moved her and his son, David, to Syracuse where he remained until his death at age 82 in 1957. He spent the majority of his working life as the department manager of an A\&P bakery.

Elizabeth DeDell, Rosemans' niece, offers the following memory in the press book: “He didn't say much about his career but, occasionally, you could get him to talk about some of the people he worked with - Mae West, Mary Pickford, Theda Bara, W.C. Fields... He showed me his make-up kit. I think he did his own make-up." DeDell confirms Roseman's railroad background, although she doesn't elaborate. Roseman's son, David, still resides in Syracuse with his son Daniel. Thus, even today the Fantomas lineage continues. 

Edward Roseman playing a similar character in the film Sands of Sacrifice, also made in 1921. As Phil Lawson - a sinister businessman operating a string of illegal mines Roseman is a commanding presence. He is both taller than Rene Navarre, who essayed Fantomas in Feuillade's serial, and less subtle. Roseman is expressive and muscular, often crouching down to confront his shorter co-stars. The film is easily available online. Roseman makes his first appearance approximately two minutes and twenty seconds into the film, casting a sinister glare toward the camera. (For a look at how Roseman might have handled the more aggressive scenes as Fantomas, skip to twentytwo minutes into the film, in which Phil Lawson assaults his young secretary.) serials of the time - which indicates that Fox Films had approached this project with a bit more ambition than was the norm. This was Fox Film's second serial production, after the successful Bride 13. It was also their last serial production. Perhaps the ambition and expense simply didn't prove to be a profitable enough formula for the studio. The first five chapters assembled in the press book give brief synopses of those serial episodes, which are reproduced below and accompanied by stills. While this only indicates a fraction of the overall story, we can still get a good idea of the tone Sedgwick was going for.

\section{On The Stroke of Nine}

\section{Document 8}

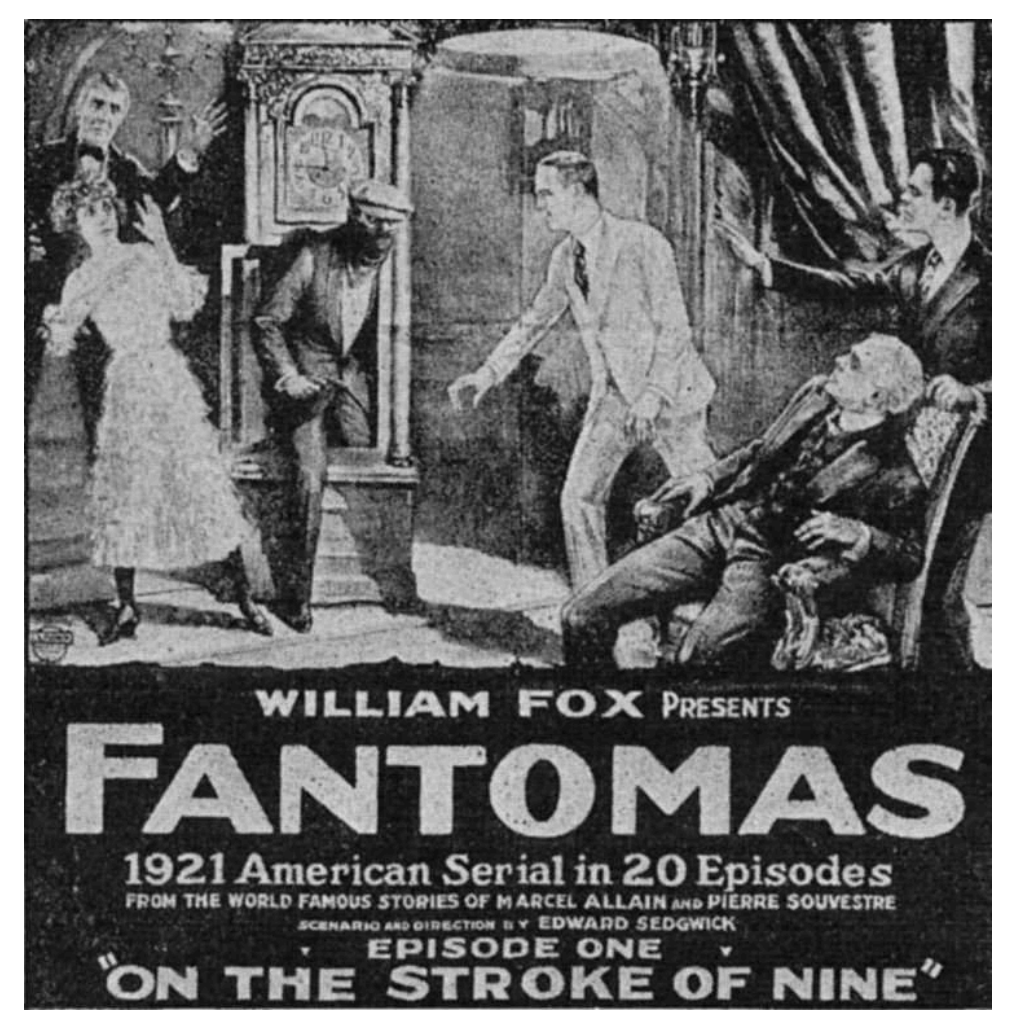

Belphégor, 11-1 | 2013 


\section{Synopsis Episode One}

19 In all the annals of criminology there does not appear a man whose brain was cleverer at devising new methods of harassing the police and civilians than that of Fantomas whose network of spies and accomplices... (this part of the press book is scratched and unreadable) One man, however, is persistent in his desire to bring Fantomas to justice knowing full well that his is a battle against death. This man is Detective Dixon. He has never seen Fantomas's face, nor has anyone else been willing to give information. Dixon has met Fantomas, but never known until the arch-criminal was beyond his reach. When he did meet him, Fantomas was always disguised. The day comes when Fantomas tires of his work and wishes to rid himself of the possibility of capture. He offers to "go straight" if the police will give him an unconditional pardon. Detective Dixon returns word to Fantomas that the police will accept nothing but unconditional surrender. Balked, Fantomas plans to kidnap James D. Harrington, millionaire and wellknown citizen; his purpose being merely to annoy the police. He sends word to Dixon of his plan and gives him the further information that the kidnapping will occur "On the Stroke of Nine" on a certain night. While he is planning Fantomas reads in the newspapers that Harrington has worked out a formula for the making of pure gold, that he intends to tell science about it and then destroy the formula because he fears to turn the financial world upside down. This makes Fantomas's criminal instinct more insistent in its desire to get Harrington. Up to this time has not met Harrington's pretty daughter Ruth. On the night the kidnapping is to take place the police surround Harrington's home. Detectives sit by his side in his big drawing room. Yet "On the Stroke of Nine" the lights go out suddenly. When they are turned on again only a sneering note is found in the chair occupied by Harrington. Harrington has disappeared. Fantomas laughs at the police.

\section{The Million-Dollar Reward}


Document 9

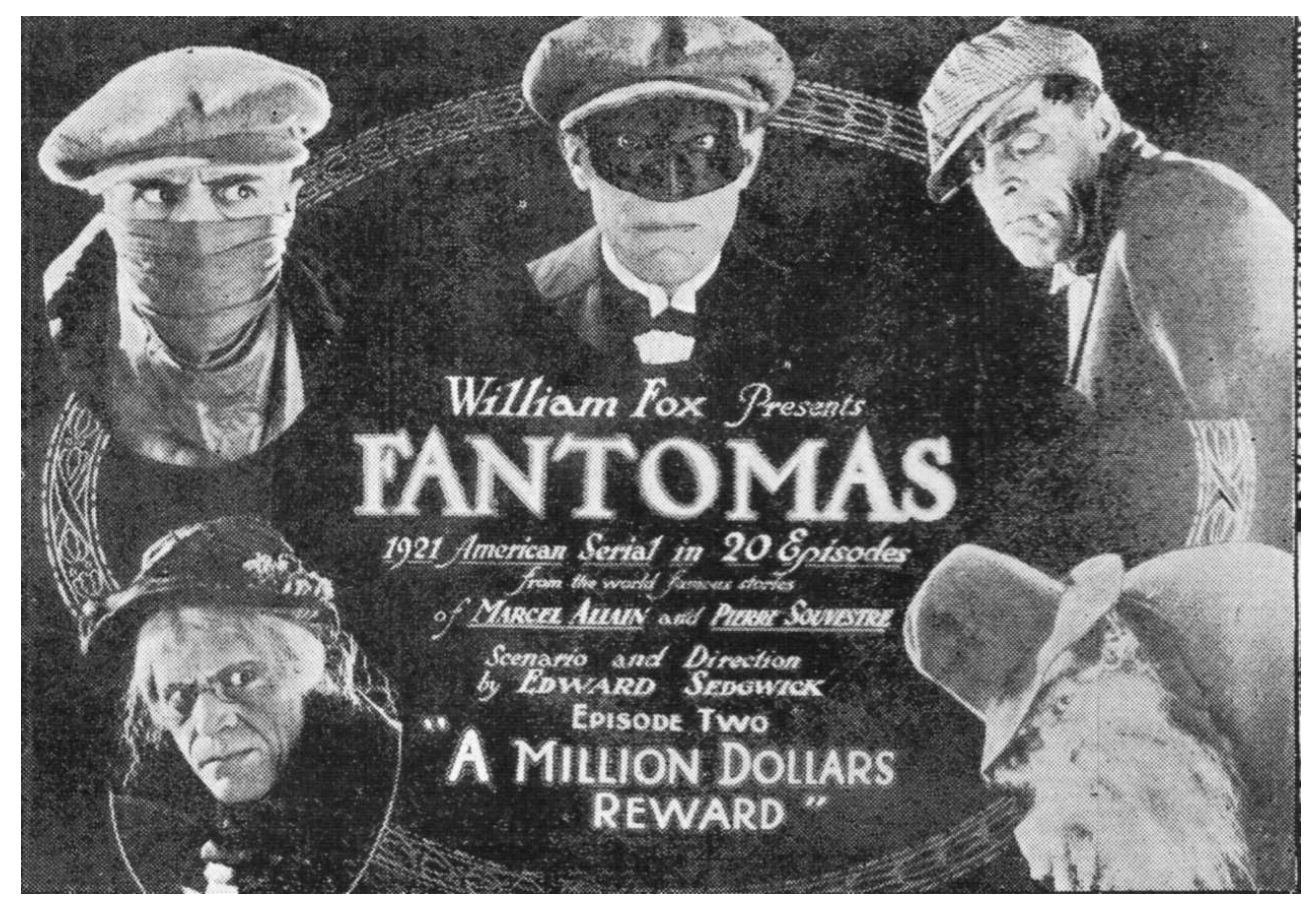

\section{Synopsis Episode Two}

20 Fantomas takes Harrington to his headquarters and locks him in a cell. He tells Harrington that he has kidnapped him to spite the police, but that since he began his plan he has heard of the gold formula, and he means to get it. A third reason has cropped up. He has seen Harrington's daughter, Ruth. He is in love with her and means to marry her. 


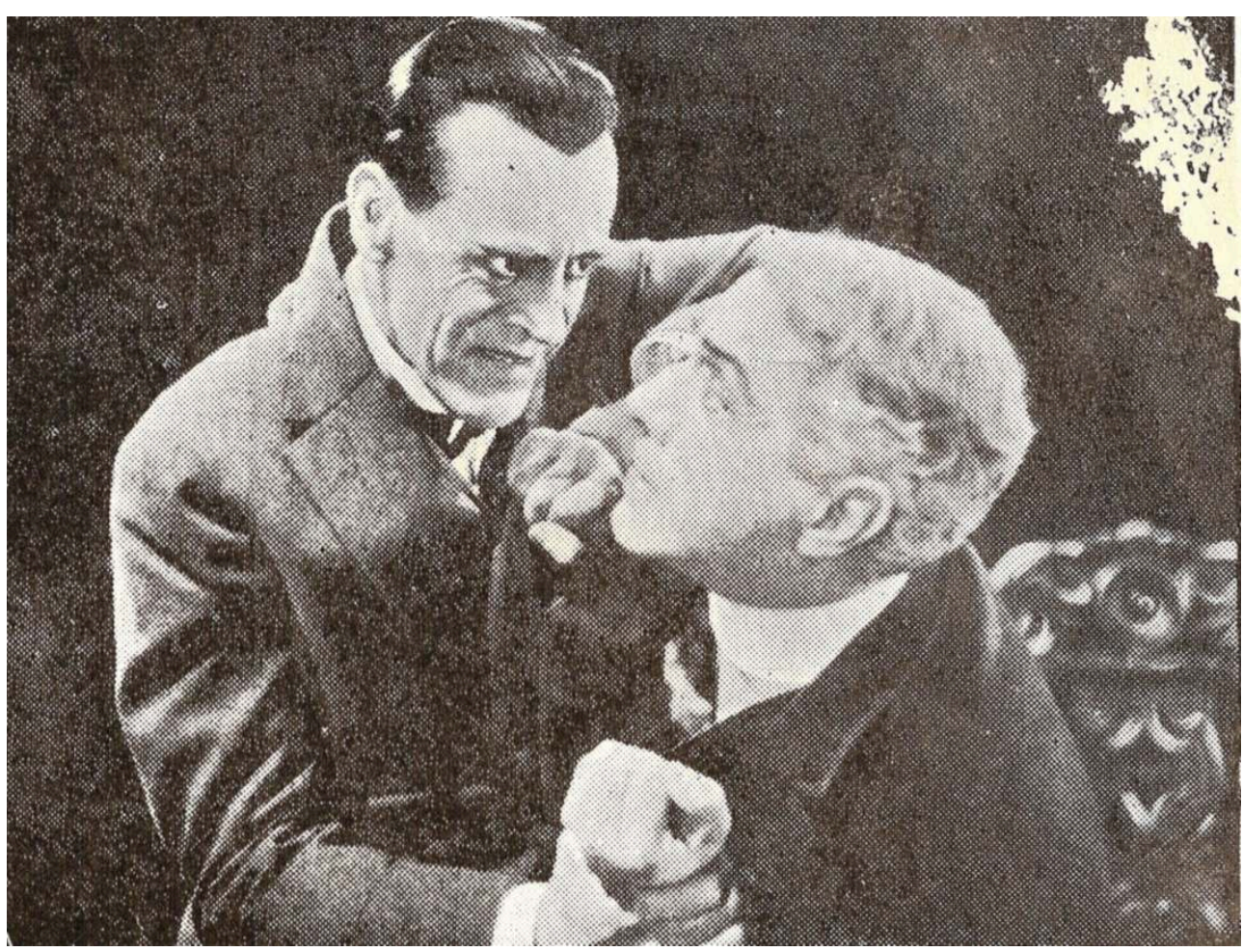

Fantomas sends one of his assistants to the Harrington home to get the formula. When the man has gone, the Woman in Black confronts Fantomas and declares that if he attempts to throw her over and marry Ruth he must take the consequences. At the Harrington home the butler has given Ruth a package. She orders him to put it in the safe. Fantomas's assistant steals the package during the night and delivers it to Fantomas, who opens it and finds it is the formula book, but - the formula has been torn out. Ruth offers $\$ 1,000,000$ reward for Fantomas. One of Fantomas's men offers to betray him. With the million dollars in a bag, Ruth, Jack (Ruth's sweetheart), Detective Dixon and the man go to a place where the man declares Fantomas will be. They get out of the auto. As they move away, the chauffeur trips Jack, who has the bag of money, and runs. It is Fantomas. 


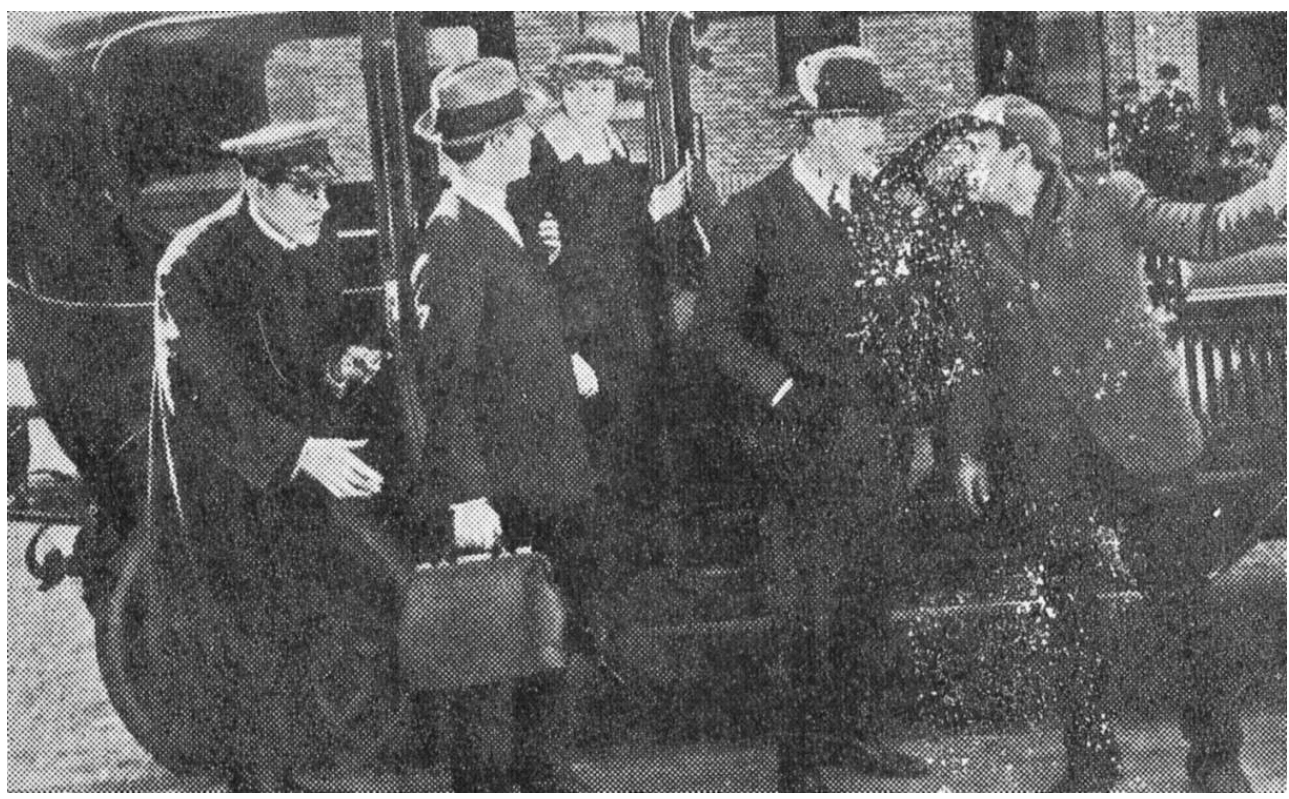

He dodges his pursuers, reaches an alleyway, puts the packages of bills into his pockets, disguises himself as Cortez, well-known international detective, walks back to the auto, and offers his card and his aid. Ruth tells him to call at her home. When Fantomas arrives home he takes out the bills. His smile changes to rage as he throws the bills on the table and cries: "Stage money!" Fantomas has met with much trouble in this Harrington matter. He becomes irritated. Before leaving to see Ruth he sends two of his men to plant a bomb at Jack's 'phone so that as soon as Jack lifts the receiver he will be blown to atoms. Fantomas, as Cortez, assures Ruth he can help her and get the reward for the capture of Fantomas. "Everyone knows Cortez the international detective," he tells her. "Call up your sweetheart and ask him about me." She calls Jack's number. There is a terrible explosion. Ruth, hearing it over the "phone, believes she has caused her sweetheart's death. She faints.

\section{The Triple Peril}


Document 12

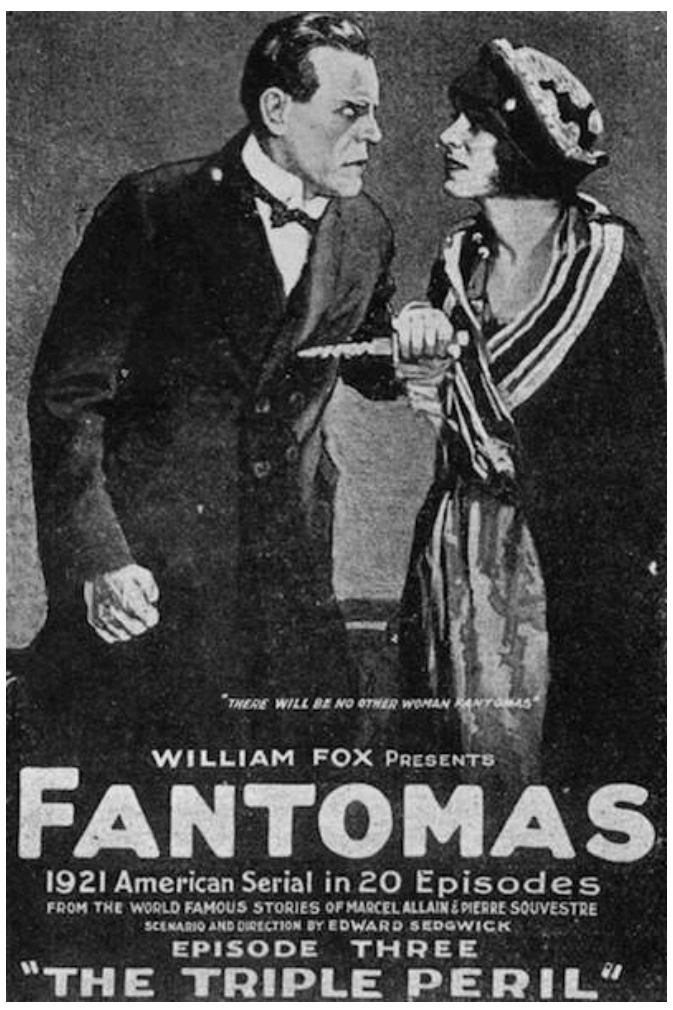

\section{Synopsis Episode Three}

23 When Jack and Detective Dixon come to after the telephone explosion, they find that they are not injured. Jack feels sure something has happened to Ruth. He and Dixon rush out and whirl away in their car. In the Harrington home Ruth is lying on the floor, having fainted after hearing the explosion over the "phone. Fantomas gets the butler and demands the gold formula. 
Document 13

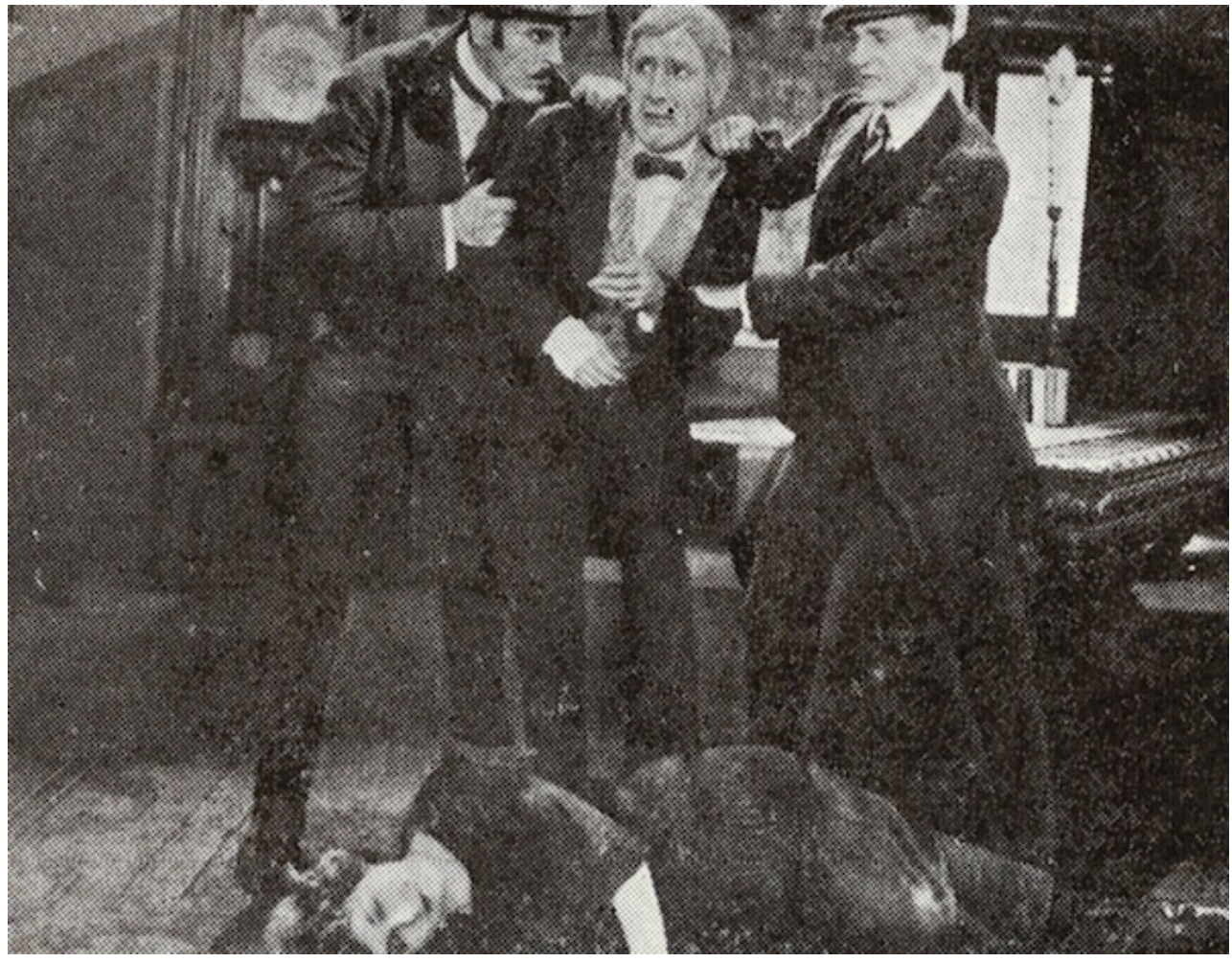

There is a struggle as Ruth revives. The butler is knocked unconscious. Jack and Dixon arrive. Fantomas picks up Ruth and hurries from the building through a window. He gets on a porte cochere. Jack and Dixon are after him. As they reach the window, Fantomas, with Ruth in his arms, jumps from the roof of the porte cochere into his auto as it speeds past. Jack and Dixon quickly get into their auto. They lose Fantomas in an exciting chase.

\section{Document 14}

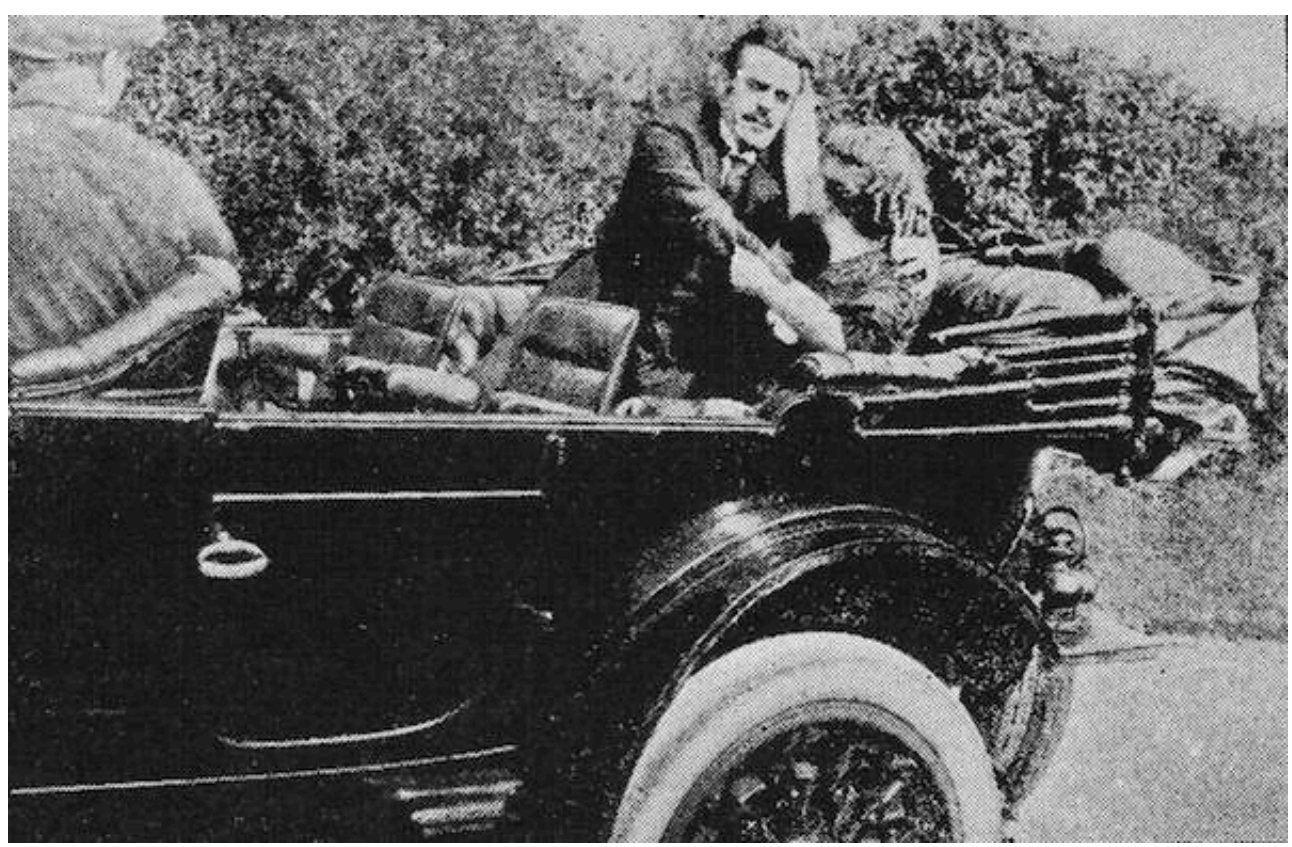


Ruth is taken to Fantomas's home and is placed in a cell-like room adjoining that in which her father is confined. Jack and Dixon separate. Jack gets a note and goes to a gambling den, where he meets the butler - who in fear gives him the gold formula. A waiter hands Jack a menu on which is written "Drop that paper and get out." A fight starts.

Document 15

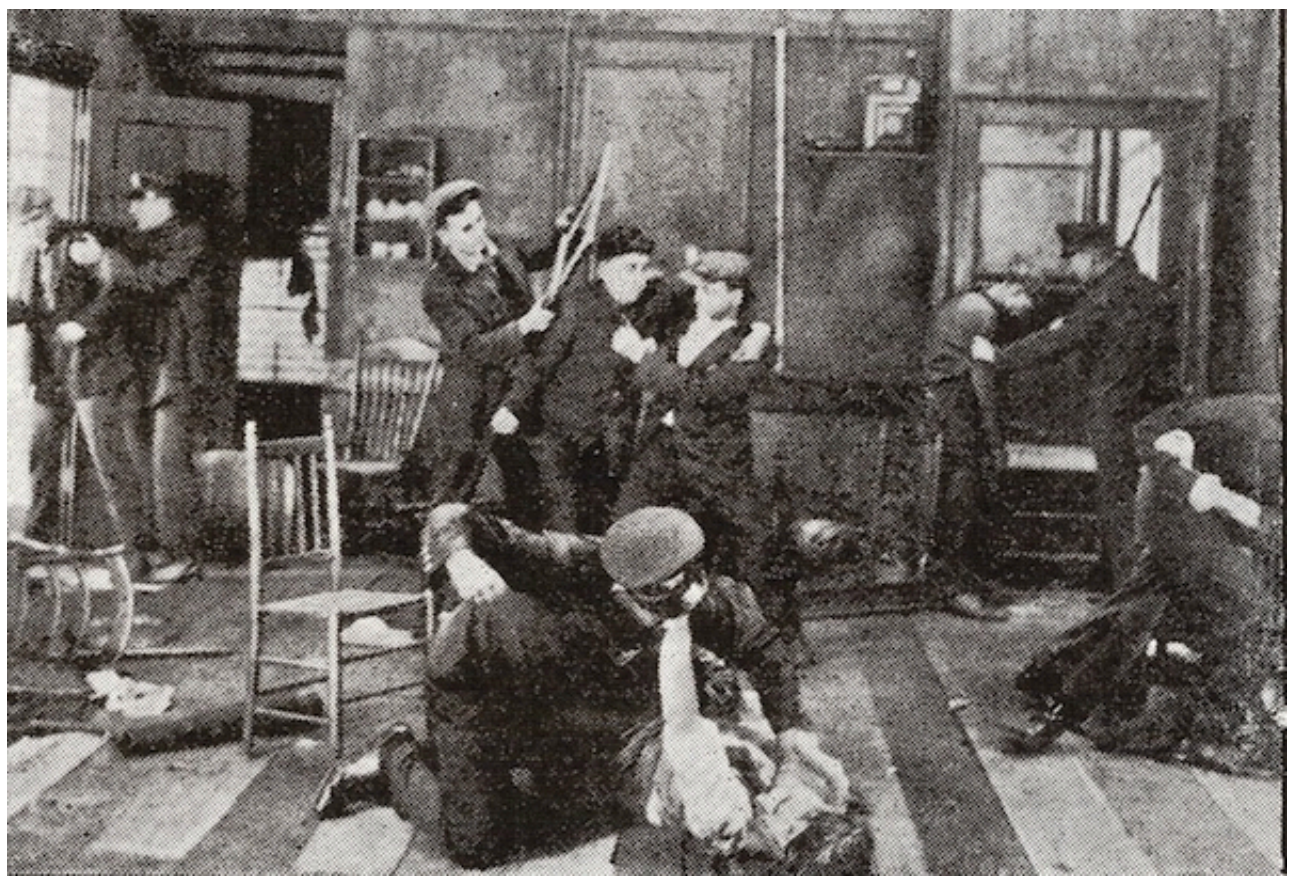

Jack swings on the chandelier and bowls his enemies over. He swings out through the door and fights his way to the roof. To avoid members of the gang there he leaps ten feet across to another building. He misses, but catches the top by his fingertips. One of the gang on this roof begins to stamp on his fingers. Below is a drop of 100 feet. In Fantomas's house Fantomas tells Ruth she must marry him. Her father in the next room hears her berate Fantomas. One of Fantomas's brutal assistants comes in brandishing a long knife. The three go to the drawing room. A minister arrives. The ugly crook stands behind Ruth, the point of his dagger touching her side. Fantomas tells the minister Ruth is nervous as it is an elopement. 
Document 16

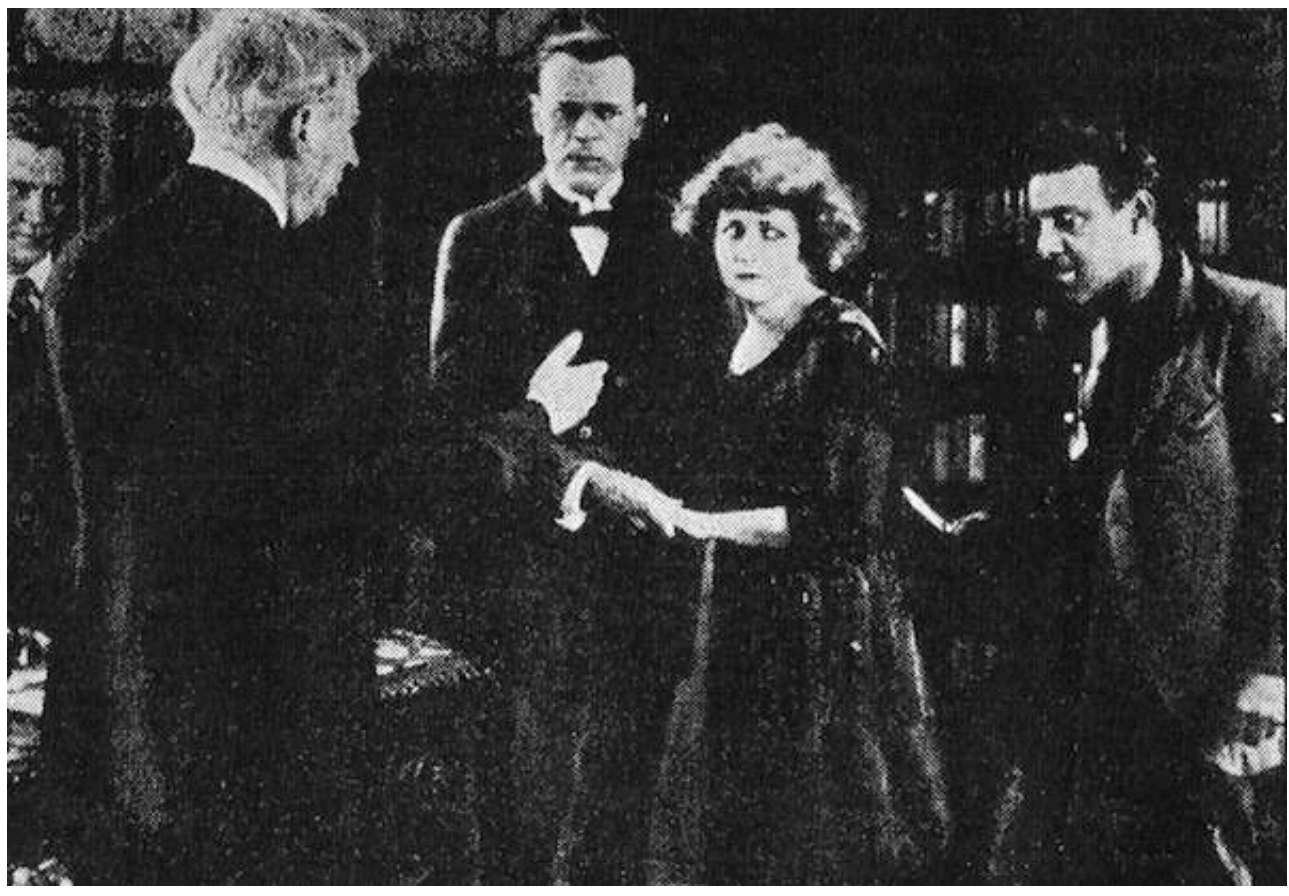

27 When the minister asks Ruth if she takes "this man" for her husband, Fantomas glares at her and the ugly crook gives a push to the knife. Ruth is terrified. Her jaws clinch. She looks at the minister. Suddenly she straightens up and cries: "No!" The crook plunges the knife as Ruth faints in Fantomas's arms.

\section{Blades of Terror}


Document 17

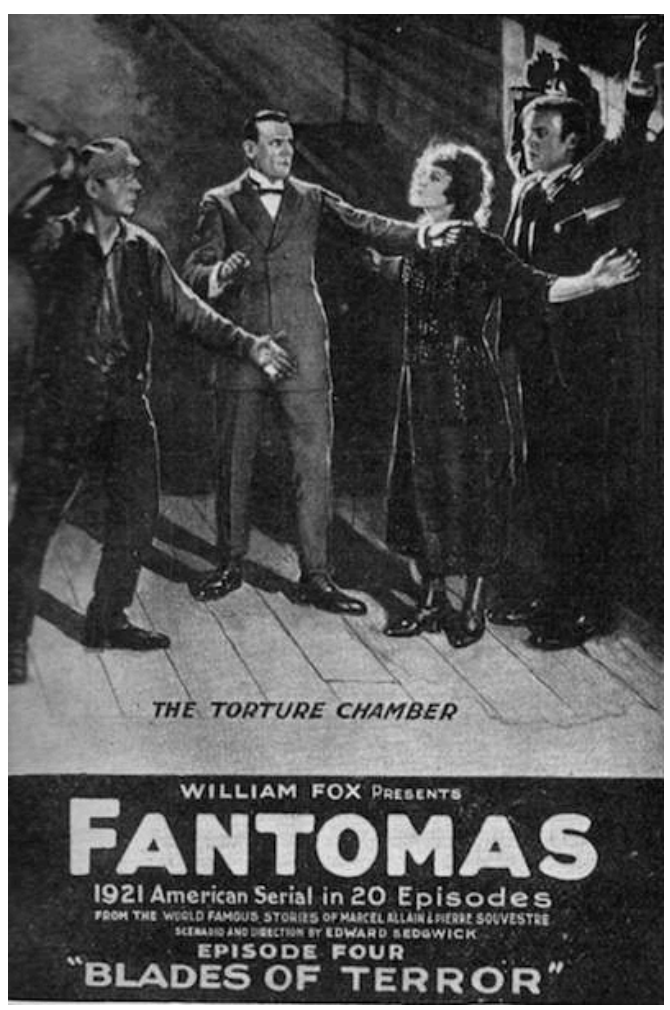

\section{Synopsis Episode Four}

When Ruth cries "No" - she will not marry Fantomas - the ugly crook plunges the knife toward her side; but the minister clutches his wrist, forces him to drop the knife, and quickly pulls Ruth to his side. Fantomas points a pistol at him, but he laughs in Fantomas's face. Jack, in the meantime, is hanging by one hand from a roof after his battle with the crooks. As Fantomas's agent is about to stamp again on Jack's hand to release his hold, a man at a window near which Jack is hanging opens the window, pulls Jack in and allows him to escape. The gang follows Jack, finally captures him, pushes him into a cab and hurries away. 


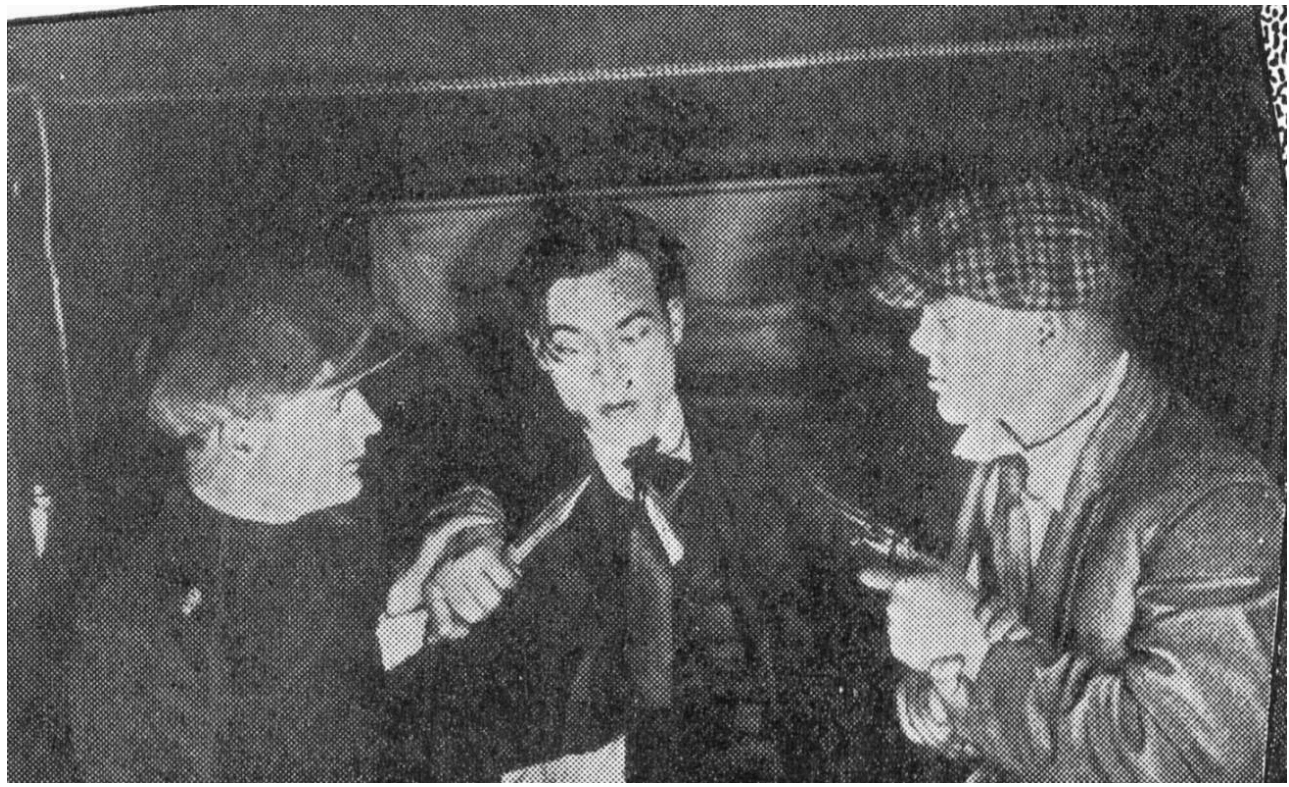

Detective Dixon, after an encounter with the Woman in Black, learns that Fantomas is about to marry Ruth. He gathers the police and bursts into Fantomas's headquarters. As the police enter, Fantomas orders the minister bound and gagged, has his men gather Harrington and Ruth, presses a button, and the floor sinks into an underground passage. In this way, Fantomas escapes through a sewer to a waiting motor boat. Dixon and the police follow in another motor boat.

\section{Document 19}

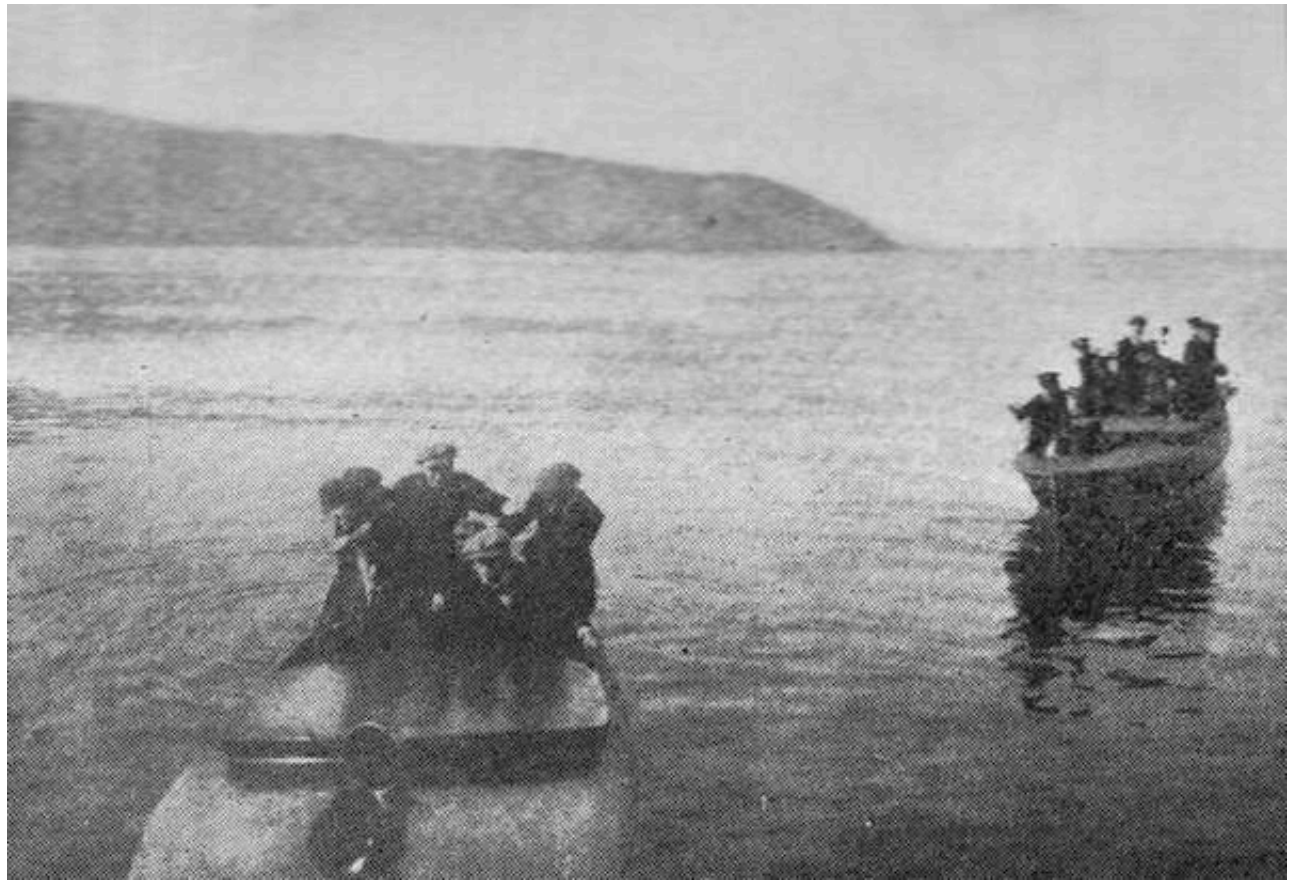

The boat is blown up. Fantomas finally gains a secret passage into another of his hiding places - his country home on the shore of Long Island Sound. In this country home he places Harrington, Ruth's father, in a cell and then pleads with Ruth to marry him. 
Document 20

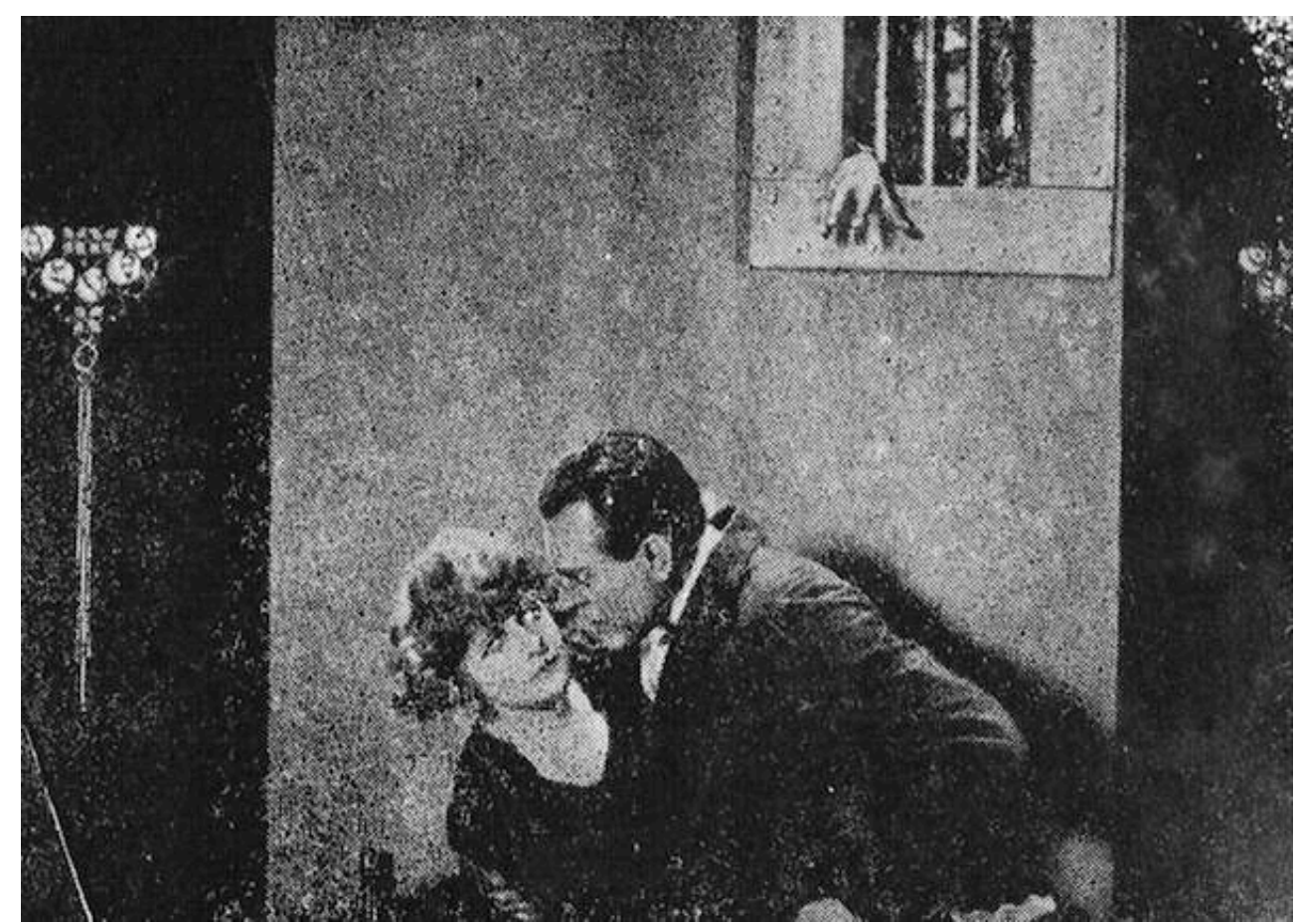

31 The Woman in Black walks in on this scene and Fantomas, sneering at her, orders Ruth taken to her room. The crooks who have Jack, search him and find the pages containing the gold-making formula. They hurry with Jack to Fantomas's country place, hand Fantomas the formula, and show him they have Jack. Fantomas soon finds that the formula is in chemist's hieroglyphics. He goes to Harrington who refuses to decipher the formula. While Fantomas is away the Woman in Black walks into Ruth's room, puts poison in a glass, pours water into it, and asks Ruth to drink. Ruth, suspicious, asks the Woman in Black to drink first. Enraged, the Woman in Black attacks her. There is a fierce struggle, which Ruth wins as Fantomas enters. He takes her out and tells her that only her marriage to him will save her father and her sweetheart Jack. 
Document 21

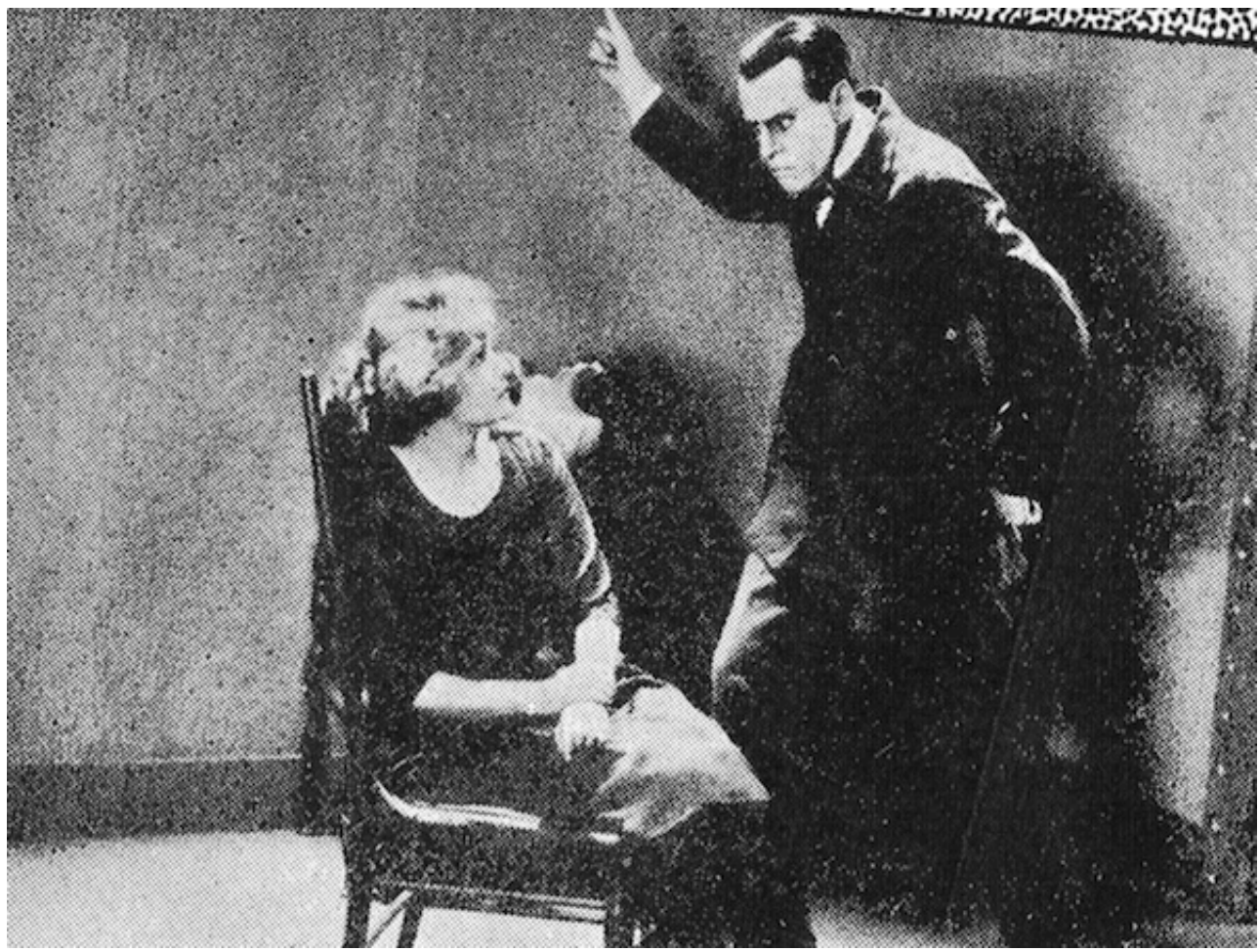

She again refuses. Fantomas smiles. He leads her to an open door. She sees Jack strung up by his thumbs. A knife wielder is throwing knives near his throat. "Your 'yes' will save his life," Fantomas tells Ruth. She looks in agony at Jack. He tells her to refuse. She does and Fantomas orders the knife wielder to throw the knife that will snuff out Jack's life.

\section{Heights of Horror}




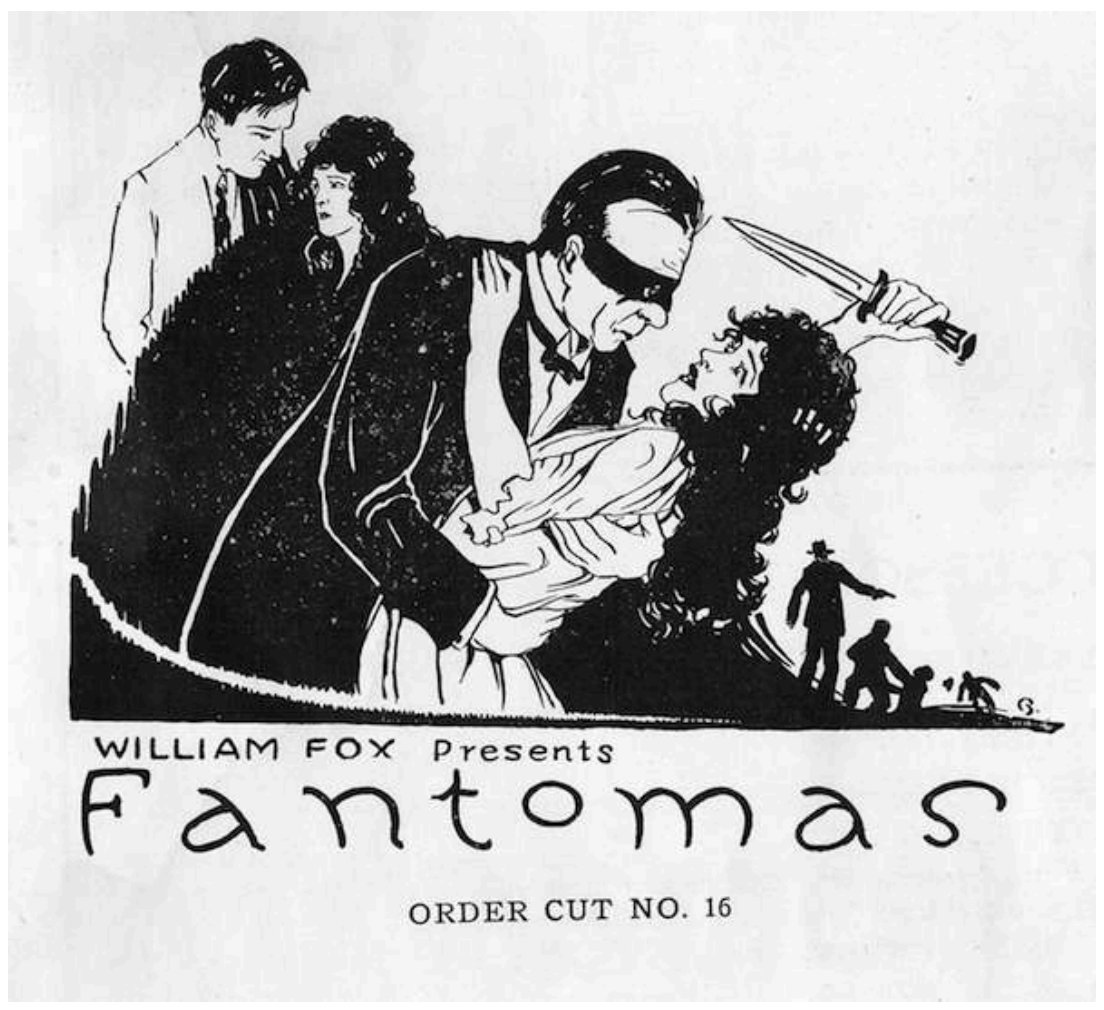

\section{Synopsis Episode Five}

Ruth is terror-stricken as the knife-thrower poises himself to fling the knife that is destined to kill Jack before her eyes. Fantomas stands grinning at her side. She can save her sweetheart if she promises to marry Fantomas. Her refusal is the order for Jack's death. As the knife-thrower's arm is about to fling the knife at Jack strung up to the wall Ruth breaks from her captors and throws herself on Jack. 


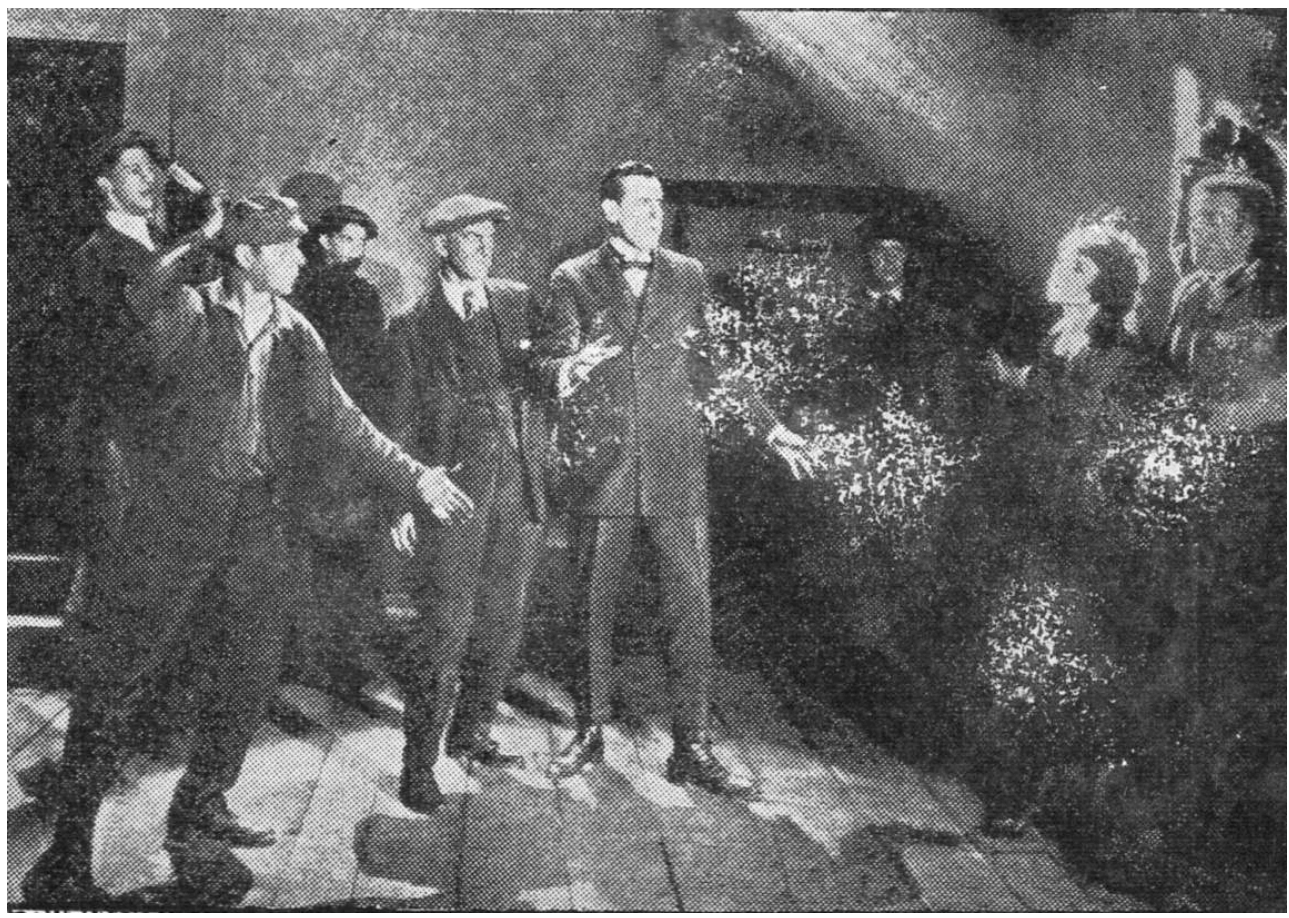

The man throws - but is disconcerted by Ruth, and the knife misses its mark. Fantomas is about to rush at Ruth, but the Woman in Black touches his arm. He stops. She tells him she has a better plan. While Fantomas's back is turned Ruth cuts Jack free and each taking a knife, they rush at Fantomas and his gang. The gang falls back and Ruth and Jack make their way to the roof, swing from the halyards of a flagpole to a tree and escape in a motor boat. Fantomas, however, shoots a hole in the motor boat and the pair are again captured. Detective Dixon suddenly walks into a room in Fantomas's house where Jack is tied up. He frees Jack and they start to get Ruth, when the guards see them and give chase. Both rush into a secret passage. As they near the end of this, several members of the gang come in. 


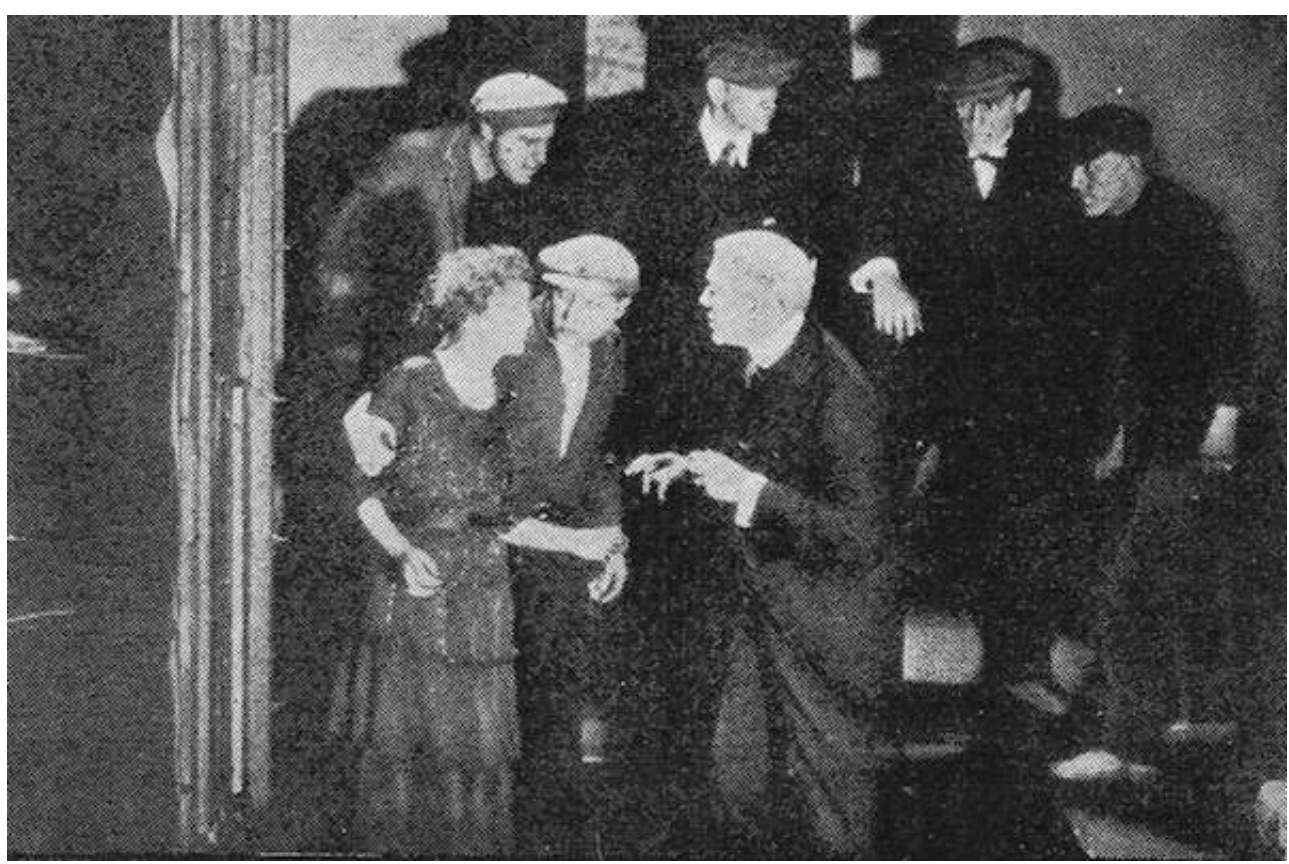

These men meet the guards and they fight among themselves as Jack and Dixon escape and hide in the tall grass. Fantomas again demands that Harrington decipher the goldmaking formula. After many subtle suggestions as to the fate of Ruth, Harrington gives in. Then Fantomas tells Harrington he will destroy the formula and go straight as Cortez, the detective, if Harrington will consent and get Ruth to agree to a marriage. Harrington, taken aback, says he must see Ruth first. The Woman in Black is listening at the door. The possibility of losing Fantomas enrages her. The Woman in Black goes silently to Ruth's room and tells the guard he can have Ruth for his own. This man and another guard throw dice for Ruth as Ruth watches. Ruth struggles with the winner. She throws a chair at him. The chair goes through the window. Jack and Dixon see it. Jack climbs to the window and gives battle to the guard. Ruth dives headlong from the window to the water below. Jack follows her. Dixon swims out to save Ruth. All three swim to shore and begin the hazardous climb of the steep cliffs. Jack reaches the top first and, holding by his finger tips, tries to help Ruth and Dixon. As he begins to pull them up slowly, one of Fantomas's men creeps slowly to the ledge, laughs fiendishly and, with dagger raised, is ready to cut Jack's grip and send all three hurtling down the Cliffside. 
Document 25

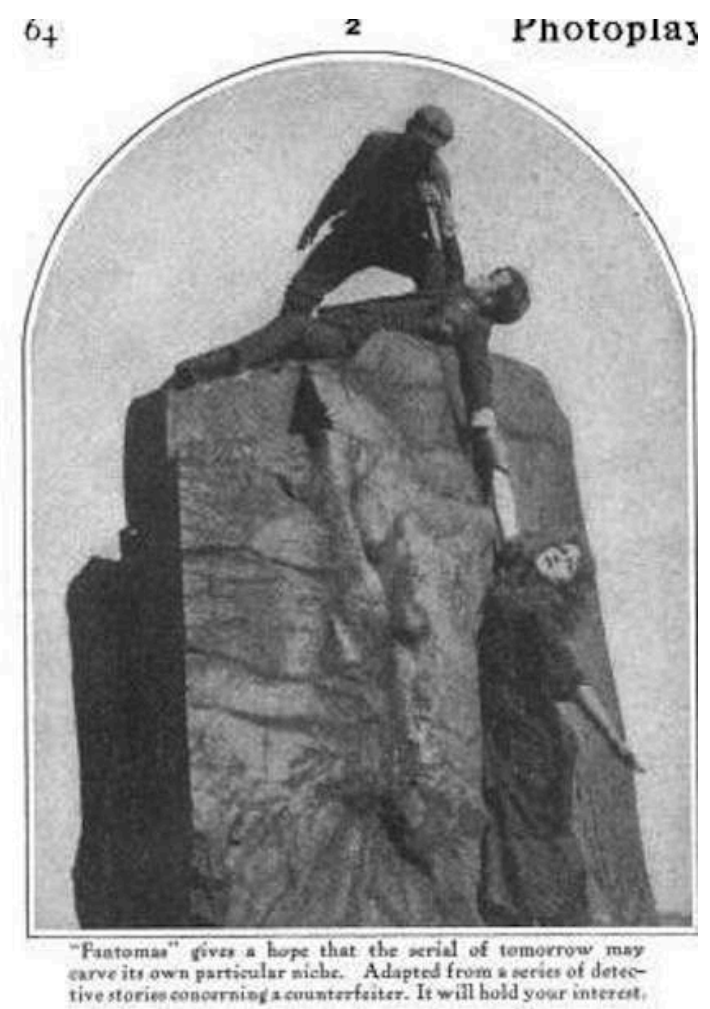

Unfortunately, no materials detailing the subsequent fifteen chapters have turned up. All we have are chapter titles:

6 - Altar of Sacrifice

7 - Flames of Sacrifice

8 - At Death's Door

9 - The Haunted Hotel

10 - The Fatal Card

11 - The Phantom Sword

12 - The Danger Signal

13 - On the Count of 3

14 - The Blazing Train

15 - The Sacred Necklace

16 - The Phantom Shadow

17 - The Price of Fang Wu

18 - Double Crossed

19 - The Hawk's Prey

20 - The Hell Ship

While it's impossible to know what these remaining chapters entail, it's safe to say that the serial is virtual compendium of pulp conventions of era, with everything from runaway trains, to sacred necklaces and mysterious Asians named Fang Wu.

The few reviews of Sedgwick's Fantomas that can be located are generally enthusiastic, although it's difficult know whether they wrote honest, objective reviews or simply studio-generated hype masquerading as such. An issue of Photoplay published the following unaccredited review: 
Now comes William Fox with "Fantomas" and gives us at least a passing hope that the serial of tomorrow may emerge from obscurity and carve its own particular little niche. From a series of famous detective stories concerning a daring counterfeiter who kidnaps the discoverer of a formula for making chemical gold, and openly defies the police to catch him, there has been built up a logical sequence of events, with excellent, with excellent direction, beautiful photography and intelligent portrayal of the various roles. Despite all the usual serial thrills, the plot is fairly coherent - and whether you are a serial addict or not, "Fantomas" will hold your interest.

A logical sequence of events? No wonder Marcel Allain hated it!

The serial was originally to have premiered in France under the title Fantômas en Amerique ("Fantomas in America") in September of 1921. Once Marcel Allain had a look at it, however, those plans were scuttled and Fox Films was forced to create new intertitles for the film which renamed the main character Diabolos. The serial was then retitled Les Exploits de Diabolos and released a year later, in September of 1922. As if the serial hadn't suffered enough indignities by that point, many of the chapters were excised and the Les Exploits de Diabolos was reduced to a more saleable twelve episodes:

1 - L'heure fatale (On the Stroke of 9)

[CUT - The Million Dollar Reward]

[CUT - The Triple Peril]

2 - Les lames d'épouvante (Blades of Terror)

[CUT - Heights of Horror]

3 - L'autel du sacrifice (Altar of Sacrifice)

4 - Dans les flammes (Flames of Sacrifice)

[CUT - At Death's Door]

5 - La maison hantée (The Haunted Hotel)

6 - L'évasion (The Fatal Card)

[CUT - The Phantom Sword]

[CUT - The Danger Signal]

[CUT - On the Count of 3]

7 - Coeur loyal (The Blazing Train)

8 - Le collier sacré (The Sacred Necklace)

[CUT - The Phantom Shadow]

9 - Fang Wu (The Price of Fang Wu)

10 - Devant Confucius (Double Crossed)

11 - La fuite (The Hawk's Prey)

12 - Le triomphe (The Hell Ship)

That might have been the end of the 1921 Fantomas serial if I hadn't stumbled across the press book on ebay in 2005. But soon after acquiring it, I decided to add my own contribution to Fantomas lore. After examining the press book's contents, I sent a proposal to Jean-Marc Lofficer at Black Coat Press, offering to write a brief novella dramatizing the first five chapters covered by the press book synopses. The more I worked on the book, however, the more it took on a life and world of its own. I entitled it Fantomas in America with the idea of giving Les Exploits des Diabolos back to Marcel Allain in a manner he might have approved of and, in the process, giving Fantomas aficionados another story to sink their teeth into. All of the events from the plot synopses are intact, but they are surrounded by new characters, events and ideas drawn from Fantomas' one hundred year history. The novella grew into a novel and it 
was released in November of 2007, illustrated with all the stills seen here, plus about a dozen more.

While the full story of the 1921 Fantomas remains terribly elusive to an English speaking audience, French readers are in luck. The novelization of the abridged French version of the serial, written by F. J. Janin, recently became available as a downloadable pdf from the Bibliotheque Nationale de France website < http://gallica.bnf.fr/ark:/ 12148/btv1b52000928s >.

Let us hope that Fantomas can, perhaps, achieve the sinister notoriety in America that he once enjoyed during the early part of the $20^{\text {th }}$ Century, when the character appeared in books, newspapers, and cinema. The Lord of Terror lives!

\section{Document 26}

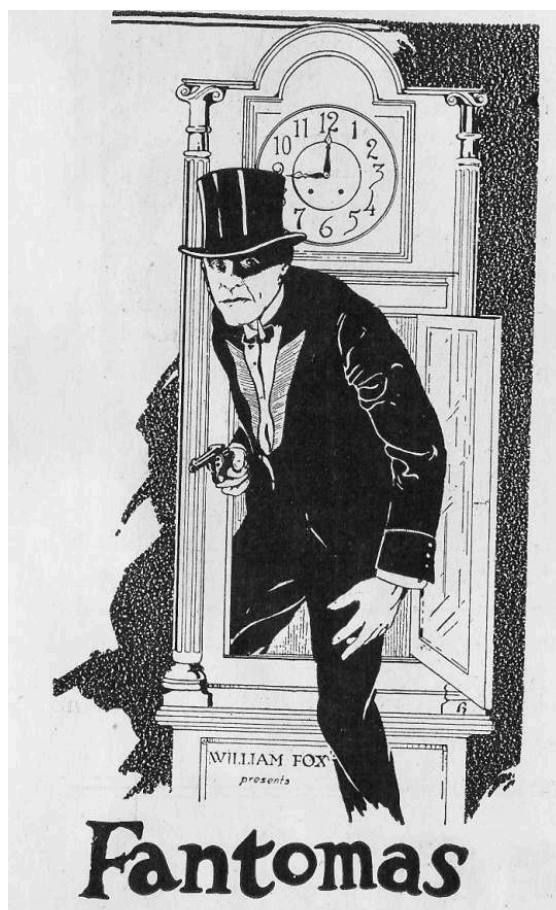

ORDER CUT NO. 7

\section{BIBLIOGRAPHY}

Fantomas: The 1921 American Serial in 20 Episodes. Adaptation and scenario by Edward Sedgwick, assisted by George Eshenfelder. Directed by Edward Sedgwick. New York: William Fox, 1921.

Janin, F.J. Les Exploits de Diabolos. Ciné-roman adapté par F.-J. Janin. Paris: J. Ferenczi, 1923.

Mantle, Burns. "The Shadow Stage.” Review "Fantomas - Fox.” Photoplay Vol. XIX, no. 4 (March 1921): 64, 104. 
McCormick, Mike. "Terre Haute native Edward Roseman motion-picture fixture in 62 films." Terra Haute Tribune-Star, 18 August 2002.

White, David. Fantômas in America. Encino, Calif.: Black Coat Press, 2007

\section{ABSTRACTS}

Since its first publication in 1911, Fantômas

has achieved iconic status all over the world, although it remains relatively unknown in America today. However, this has not always been the case. At the time of the character's inception, English translations of the Fantômas novels appeared in newspapers and bookstores across the country, and Feuillade's Fantômas film serial was distributed in America as well. In 1920, the Fox Film Corporation decided to capitalize on the character's popularity by producing an American Fantomas serial, directed by Edward Sedgwick. By 1920, however, the notoriety of Fantômas had already begun to dissipate in the United States. Only twelve of the novels in the original thirtytwo volume series were ever translated into English, and most traces of Sedgwick's film serial vanished without a trace. Fortunately, the recent discovery of a press book of Fantomas (1920), containing photo-stills, plot synopses and press copy, provide us with some insight into this lost film.

\section{INDEX}

Keywords: Fantômas, cinema, serials, America, France, Feuillade Louis, Fox, Sedgwick Edward

\section{AUTHOR}

\section{DAVID WHITE}

David Lee White is a novelist and playwright, currently serving as the Associate Artistic Director of Passage Theatre in Trenton, New Jersey. The author of the novel Fantomas in America (Black Coat Press, 2007), he is a life-long devotee of early crime fiction. White recently premiered his play Slippery as Sin, which was inspired by early pulp fiction like Fantomas, Sexton Blake and Nick Carter. White has been called "A post-modern Neil Simon" (New Jersey Star-Ledger) and his play Blood: A Comedy, was praised by the New York Times who said, “Blood: A Comedy couldn't be cleverer as it deals with the onset of Alzheimer's disease, a soap-opera-style family shocker and reflections on the existence of God." Writing about White's Slippery as Sin, Talkin' Broadway said "I would not be surprised if Slippery as Sin goes on to become a popular, widely produced staple of the American stage." White is also a fan of obscure, cult-cinema, and he has written a number of pieces for Video Watchdog with Kaya Ozkaracalar, including "Yilmaz Atadeniz: Superman of Turkish Cinema," one of the earliest, in-depth articles about Turkish cult cinema to appear in English. 